\title{
Upaya Meningkatkan Keterampilan Membedakan Toilet Pria dan Toilet Wanita Melalui Media Kartu Gambar di SLB Amanah Bunda Sitapung Ampek Angkek
}

\author{
Gina Hapsari \& Kasiyati \\ Universitas Negeri Padang, Indonesia \\ Email: hapsarigina@gmail.com
}

\begin{abstract}
This study aims to improve children's skills in distinguishing male toilets and female toilets which are carried out through self-drawing cards. This research was conducted 13 times observation. This research method uses a Single Subject Research (SSR) type of study with A-B-A design. Baseline condition (A1) is the initial capability before it is given as many as four observations. The intervention condition $(B)$ is a condition given after six examinations have been carried out. While the baseline condition (A2) is a dismissal carried out three times. Data analysis techniques using visual graph analysis. The percentage of overlap obtained at condition $A 1 / B$ is $0 \%$ while the percentage of overlap obtained at condition $A 2$ / B is $50 \%$. Based on the results of this study, the image card media is effective in improving the skills of calculating male and female toilets.
\end{abstract}

ABSTRAK

Penelitian ini bertujuan untuk meningkatkan keterampilan anak dalam membedakan toilet laki-laki dan toilet perempuan yang dilakukan melalui media kartu gambar. Penelitian dilaksanakan selama 13 kali. Metode yang digunakan penelitian Single Subject Research (SSR) bentuk A-B-A. Kondisi baseline (A1) dilakukan empat kali. Kondisi intervensi (B) merupakan kondisi setelah diberikan perlakuan dilakukan sebanyak enam kali. Sedangkan kondisi baseline (A2) merupakan pemberhentian perlakuan dilakukan sebanyak tiga kali pengamatan. Analisis grafik visual sangat diperlukan salam teknik analisis data. Persentase overlap diperoleh pada kondisi A1-B yaitu $0 \%$ sedangkan persentase overlap yang diperoleh pada kondisi A2-B yaitu 50\%. Berdasarkan hasil penelitian ini maka dalam meningkatkan keterampilan untuk membedakan toilet laki-laki dan toilet perempuan efektif menggunakan media kartu gambar.

Katakunci: Kartu gambar, toilet, tunagrahita ringan

\section{Pendahuluan}

Manusia diciptakan oleh Tuhan dengan berpasang-pasangan, ada berjenis kelamin pria dan wanita. Mereka dibekalipemikiran dan kecerdasan dalam menjalankan kehidupanyang baik supaya kehidupan yang dijalani bermutu sehingga diperlukan pendidikan bermutu, sehingga mampu dijadikan bekal hidup masa depannya. Dalam meningkatkan kualitas manusia pendidikan harus memiliki kedudukan penting agar dapat melahirkan lingkungan untuk menunjang bakat dan minat siswa secara optimal. 
Pemberian pendidikan kepada peserta didik sangat berguna untuk membangun manusia dan menunjang kemampuan anak. Anak berkebutuhan khusus juga memerlukan pendidikan, tidak hanya kepada anak normal saja. Hambatan yang dimiliki seperti fisik, mental, kecerdasan, mental dan sosialisasi.

Penyelenggara pendidikan untuk anak berkebutuhan khusus harus disesuaikan dengan layanan yang diperlukan, harus sesuai dengan hambatan yang dimiliki, kelainan atau ketunaan mereka baik berupa bentuk tubuh, kecerdasan, emosi dan sosial (Ganda Sumekar, 2009).

Anak yang mempunyai integensi dibawah intelegensi normal atau rata-rata disebut anak tunagrahita (Dodo Sudrajat \& Lilis Rosida, 2013). Hak dan kewajiban yang diperlukan oleh mereka adalah dapat hidup mandiri, walaupun anak memiliki keterbatasan serta lambat dalam berfikir, berhubungan sosial dan berbaur di lingkungan sekitarnya dibandingkan teman sejawatnya.anak tunagrahita ringan memiliki IQ 50-68 (Kasiyati \& Kusumastuti, 2019).

Anak tunagrahita ringan memiliki kemampuan lamban dalam perkembangan konsep, sosial, dan keterampilan sehari-hari. Anak tunagrahita bisa mempelajari keterampilan sehari-hari dengan mengikutsertakan mereka dalam kegiatan sehari-hari. Anak tunagrahita ringan dapat menjaga dirinya sendiri, bersosialisasi dengan komunitas, dan belajar keterampilan dasar tentang keamanan dan kesehatan.

Klasifikasi anak tunagrahita bermacam-macam, salah satunya adalah anak tunagrahita kategori ringan. Anak tunagrahita kategori ringan merupakan anak yang mengalami keterbelakangan kecerdasan/mental dan terlambat dalam menyesuaikan prilaku terhadap lingkungan. Disamping itu mereka tidak mampu berfikir abstrak, logis, dan sukar dalam memusatkan perhatian dan mengungkapkan kembali suatu ingatan yang sudah didapatnya.

Pentingnya kurikulum bagi anak tunagrahita kategori ringan adalah untuk mencetak generasi berkarakter. Anak tunagrahita kategori ringan, tidak hanya meminta belas kasihan dan bantuan kepada masyarakat untuk melakukan sesuatu, tetapi anak tunagrahita kategori ringan harus bisa menampilkan kemandirian tanpa bantuan orang lain, sehingga rasa kasihan masyarakat tidak ada, tetapi rasa kekaguman yang dimiliki oleh anak tunagrahita kategori ringan. Salah satunya tentang kebersihan dan kemandirian anak tunagrahita kategori ringan yaitu membedakan toilet pria dan toilet wanita. Toilet merupakan tempat untuk buang air kecil (BAK) dan buang air besar (BAB).

Berdasarkan studi pendahuluan yang dilakukan di SLB Amanah Bunda Sitapung Ampek Angkek Kab. Agam, Sumatera Barat peneliti mengamati siswa kelas D.III C yang siswanya berjumlah 3 orang anak tunagrahita kategori ringan. Waktu istirahat, terjadi keributan di toilet siswa yang disebabkan oleh ZK pergi ke toilet wanita bukan ke toilet pria 
yang ternyata ZK tidak bisa membedakan toilet pria atau toilet wanita. Keesokkan harinya ZK dan JF bersama-sama pergi ke toilet. Ternyata mereka berdua tidak masuk ke toilet yang sama, mereka berbagi toilet saja, JF ke toilet pria dan ZK ke toilet wanita. Ketika peneliti bertanya kepada ZK kenapa masuk ke dalam toilet yang bukan jenis kelaminnya, anak menjawab kalau tidak tahu yang mana toilet pria dan toilet wanita dikarenakan toilet pria dan toilet wanita ditulis menggunakan tulisan sedangkan anak masih belum bisa membaca. Hasil wawancara dengan guru, ternyata anak memang belum bisa membaca sehingga anak belum bisa membaca tulisan yang tertera di pintu toilet. Maka peneliti menggunakan media kartu gambar menggantikan tulisan yang tertera di pintu toilet. Media gambar adalah termasuk media visual, pesan yang disampaikan dituangkan dalam simbol-simbol komunikasi verbal dan berfungsi menarik perhatian siswa (Arief S. Sadiman, R. Rahardjo, Anung Haryono, \& Harjito, 2014).

Penelitian bertujuan untuk membuktikan media kartu gambar dapat meningkatkan keterampilan membedakan toilet pria dan toilet wanita pada anak tunagrahita kategori ringan. Media gambar adalah termasuk media visual, pesan yang disampaikan dituangkan dalam simbol-simbol komunikasi verbal dan berfungsi menarik perhatian siswa serta memiliki beberapa manfaat seperti untuk peneliti sebagai penambah wawasan, bagi pendidik sebagi pedoman membedakan toilet, serta bagi peneliti selanjutnya untuk mengembangkan kajian teori dalam membedakannya.

\section{Metode}

Dalam penelitian ini yang menjadi subjek adalah seorang siswaberinisial ZK, kelas III di SLB Amanah Bunda Sitapung Ampek Angkek Kab.Agam.Peneliti mengumpulkan data melalui observasi, tes dan dokumentasi untuk mengetahui apakahketerampilan anak dalam membedakan toilet pria dan toilet wanita sudah baik. Pada tahap A1tes diberikan kepada berupa tes lisan dan memperlihatkan gambar dari toilet pria dan toilet wanita. Pada tahap B, pemberian intervensi dengan menggunakan kartu gambar toilet pria dan toilet wanita. Kegiatan ini anak menyebutkan, menunjukkan serta membedakannya. Selanjutnya tahap A2 tes yang diberikan sama namun tidak memberikan intervensi kepada anak dengan tujuan untuk mengetahui perkembangan anak setelah tidak diberikan intervensi lagi.

Langkah-langkah penggunaan media kartu gambar yang dapat dimodifikasi sesuai dengan penelitian ini sebagai berikut guru memperlihatkan gambar toilet, guru menjelaskan pengertian toilet, guru menerangkan jenis toilet, guru mendemonstrasikan atau memperagakan proses pembelajaran dengan media kartu gambar, misalnya :

Gambar toilet pria : 


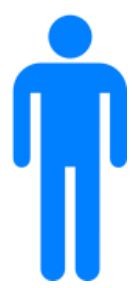

Gambar 1. Toilet Pria

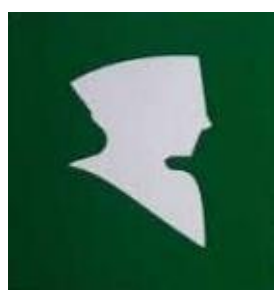

Gambar 2. Toilet Pria

Ciri-cirinya yakni bewarna biru, memakai celana atau peci.

Gambar toilet wanita :

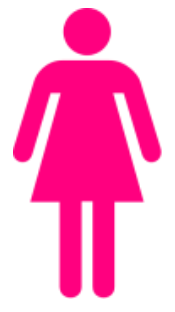

Gambar 3. Toilet Wanita

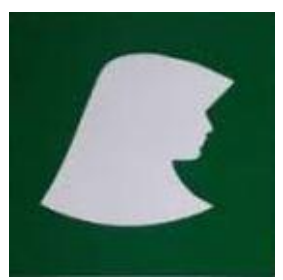

Gambar 4. Toilet Wanita

Ciri-cirinya yaitu bewarna merah atau pink, memakai rok atau jilbab.

Caranya kerjanya dengan memperlihatkan gambar toilet berdasarkan jenis kelamin, menyuruh anak untuk mengambil salah satu kartu gambar simbol toilet, anak menyebutkan kartu gambar yang diambil, kemudian anak disuruh menempel kartu yang di ambil ke pintu toilet.

\section{Hasil Penelitian dan Pembahasan}

Penelitian ini dilakukan sebanyak 13 kali pengamatan, dimulai dari tanggal 21 Oktober 2019 sampaidengan tanggal 8 November 2019. Perolehan data selama pengamatan pada kondisi A1yang dilakukan sebanyak 4 kali pengamatan yaitu dari 5 item instrumen 
penelitian anak tidak mampu melakukan ke 5 item. Karena data yang diperoleh sama, maka peneliti melanjutkan ke kondisi B.

Pengamatan yang dilakukan pada kondisi B sebanyak 6 kali pengamatan dengan menggunakan media kartu gambar,pada pertemuan pertama intervensi anak bisa melakukan 3 item yaitu menyebutkan gambar toilet pria, menunjukkan gambar toilet pria dan menunjukkan gambar toilet wanita. Pada pertemuan kedua anak bisa melakukan 4 item yaitu menyebutkan gambar toilet pria, menyebutkan gambar toilet wanita, menunjukkan gambar toilet pria dan menunjukkan gambar toilet pria. Pada pertemuan ketiga mengalami penurunan dari pertemuan sebelumnya anak hanya bisa melakukan 3 item yaitu menyebutkan gambar toilet pria, menyebutkan gambar toilet wanita, menunjukkan gambar toilet wanita. Pada pertemuan keempat mengalami peningkatan dari pertemuan sebelumnya anak bisa melakukan 4 item yaitu menyebutkan gambar toilet pria, menyebutkan gambar toilet wanita, menunjukkan gambar toilet pria dan membedakan toilet berdasarkan jenis kelaminnya. Pada pertemuan kelima anak bisa melakukan 4 item yaitu menyebutkan gambar toilet pria, menyebutkan gambar toilet wanita, menunjukkan gambar toilet pria serta menunjukkan gambar toilet wanita. Pada pertemuan keenam anak bisa melakukan 4 item seperti saat pertemuan sebelumnya yaitu menyebutkan gambar toilet pria, menyebutkan gambar toilet wanita, menunjukkan gambar toilet pria dan menunjukkan gambar toilet wanita. Karena pada kondisi B data sudah stabil pada peremuan empat dan enam, maka dilanjutkan pada kondisi A2.

Kondisi A2 dilakukan selama tiga kali pertemuan tanpa adanya perlakuan, pada kondisi ini pertemuan pertama anak bisa melakukan empat dari kelima item dari insrtumen penelitian yaitu menyebutkan gambar toilet pria, menyebutkan gambar toilet wanita, menunjukkan gambar toilet pria, menunjukkan gambar toilet wanita serta membedakan toilet pria dan toilet wanita berdasarkan jenis kelaminnya. Pada pertemuan kedua anak juga bisa melakukan empat dari kelima item yaitu menyebutkan gambar toilet pria, menyebutkan gambar toilet wanita, menunjukkan gambar toilet pria, menunjukkan gambar toilet wanita. Pada pertemuan ketiga sama seperti pertemuan sebelumnya anak bisa melakukan empat dari kelima item yaitu menyebutkan gambar toilet pria, menyebutkan gambar toilet wanita, menunjukkan gambar toilet pria, menunjukkan gambar toilet wanita.

Kondisi A1 pada pengamatan pertama, kedua, ketiga, dan keempat anak memperoleh skor $0 \%$. Kondisi B dengan diberikan perlakuan pada pengamatan pertama anak memperoleh skor 60\%, pada pengamatan kedua anak memperoleh skor $80 \%$, pada pengamatan ketiga anak memperoleh skor $60 \%$, pada pengamatan keempat dan kelima anak memperoleh skor $80 \%$. Kondisi A2 pada pengamatan pertama, kedua dan ketiga anak memperoleh skor $80 \%$. Pada kondisi A1terlihat bahwa mean level yaitu 0, memiliki BA 0 dan 
Tarbawi, Volume 5 No. 12020

Gina Hapsari \& Kasiyati, Upaya Meningkatkan Keterampilan

BB 0. Pada kondisi Bmean level yaitu 73,33, memiliki BA 79,33 dan BB 67,33. Pada kondisi A2 memiliki mean level yaitu 80, memiliki BA86 dan BB74.

Perbandingan pada setiap kondisi A-B-A dapat dilihat pada grafik di bawah ini :

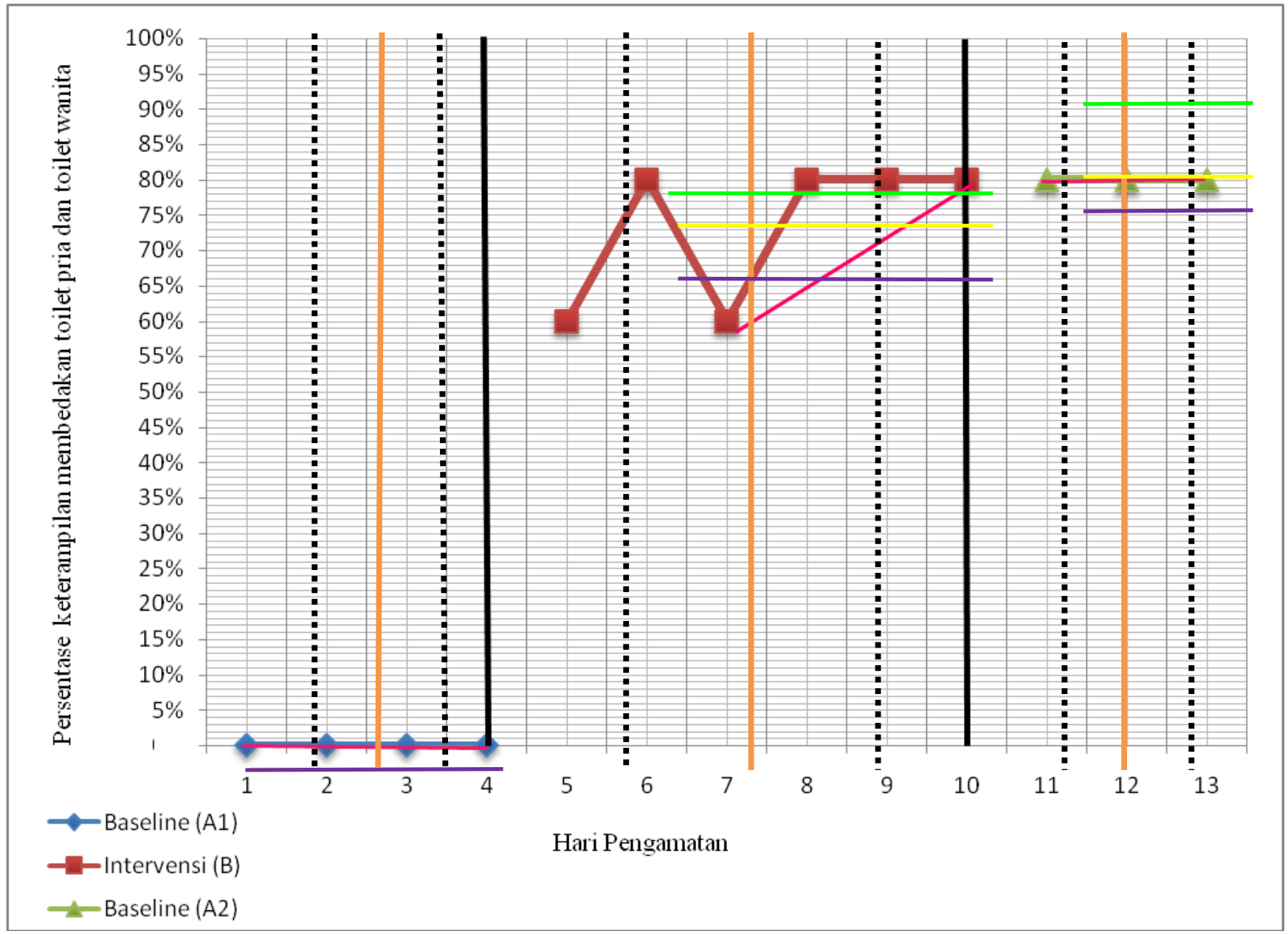

\section{Grafik 1. Kecenderungan Stabilitas Data}

Keterangan :

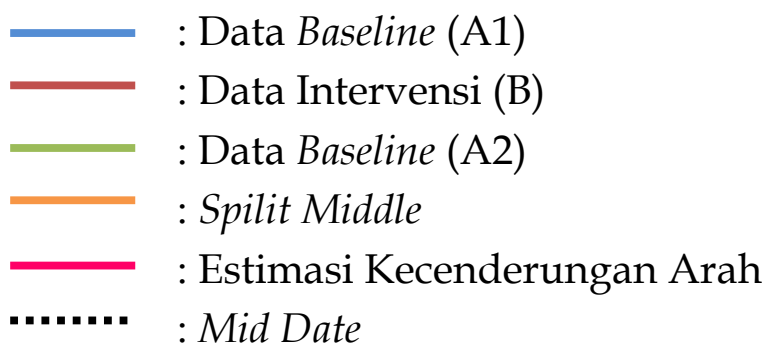




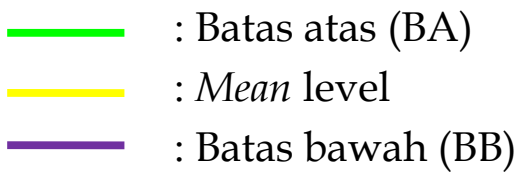

Berdasarkan analisis data yang didapat, dapat dibuktikan bahwa pengamatan yang dilakukan sebanyak 13 pertemuan keterampilan dalam membedakan toilet pria dan toilet wanita sebelum diberikan intervensi masih rendah, tetapi setelah diberikan perlakuan persentase anak mengalami peningkatan dan setelah pemberian perlakuan diberhentikan persentase yang diperoleh anak sama dengan pertemuan terakhir dari kondisi intervensi.

Tabel 1. Analisis dalam Kondisi

\begin{tabular}{|c|c|c|c|c|}
\hline No & Kondisi & A1 & B & A2 \\
\hline 1 & Panjang kondisi & 4 & 6 & 3 \\
\hline 2 & $\begin{array}{l}\text { Estimasi kecenderungan } \\
\text { arah }\end{array}$ & $(=)$ & & $(=)$ \\
\hline 3 & Kecenderungan stabilitas & $\begin{array}{c}0 \% \\
\text { (tidak } \\
\text { stabil) }\end{array}$ & $\begin{array}{c}66,66 \% \\
\text { (tidak } \\
\text { stabil) }\end{array}$ & $\begin{array}{l}100 \% \\
\text { (stabil) }\end{array}$ \\
\hline 4 & Kecenderungan jejak data & $(=)$ & & $(=)$ \\
\hline 5 & Level stabilitas dan rentang & $\begin{array}{c}\text { Variabel } \\
0 \%-0 \%\end{array}$ & $\begin{array}{l}\text { Variabel } \\
60 \%-80 \%\end{array}$ & $\begin{array}{c}\text { Stabil } \\
80 \%-80 \%\end{array}$ \\
\hline 6 & Level perubahan & $\begin{array}{c}0 \%-0 \%= \\
0 \% \\
(=)\end{array}$ & $\begin{array}{c}80 \%-60 \%= \\
20 \% \\
(+)\end{array}$ & $\begin{array}{c}80 \%-80 \%= \\
0 \% \\
(=)\end{array}$ \\
\hline
\end{tabular}

Berdasarkan hasil analisis grafik pada setiap kondisi, kecenderungan arah dari kondisi baseline (A1) tidak mengalami peningkatan. Dari kondisi intervensi (B) mengalami peningkatan. Selanjutnya pada kondisi baseline (A2) kecenderungan arah stabil. Di bawah ini merupakan rangkuman komponen analisis visual antar kondisi yaitu :

Tabel 2. Analisis Antar Kondisi

\begin{tabular}{|c|lc|c|}
\hline No & \multicolumn{2}{|c|}{ Kondisi } & A1/B/A2 \\
\hline 1 & $\begin{array}{l}\text { Jumlah variabel yang } \\
\text { diubah }\end{array}$ & 1 \\
\hline 2 & Perubahan kecenderungan & \\
\hline
\end{tabular}




\begin{tabular}{|c|c|c|c|}
\hline & arah & $(=)$ & $(=)$ \\
\hline 3 & $\begin{array}{l}\text { Perubahan kecenderungan } \\
\text { stabilitas }\end{array}$ & \multicolumn{2}{|c|}{ Ke tidak stabil Ke tidak stabil Ke stabil } \\
\hline 4 & Level perubahan & $\begin{array}{c}\text { A1-B } \\
60-0=60\end{array}$ & $\begin{array}{c}\text { B-A2 } \\
80-80=0\end{array}$ \\
\hline 5 & Persentase overlap & $\begin{array}{l}\text { A1-B } \\
0 \%\end{array}$ & $\begin{array}{l}\text { B-A2 } \\
50 \%\end{array}$ \\
\hline
\end{tabular}

Berdasarkan pengamatan analisis antar kondisi adanya peningkatan kecenderungan arah, kecenderungan kestabilan, sehingga data yang diperoleh mengalami peningkatan yang stabil, maka hal ini dapat menunjukkan bahwa keterampilan membedakan toilet pria dan toilet wanita meningkat melalui media kartu gambar.

\section{Kesimpulan}

Berdasarkan hasil penelitian, dapat disimpulkan bahwa media kartu gambar dapat meningkatkan keterampilan anak membedakan toilet pria dan toilet wanita.

Pengamatan dalam penelitian ini dilakukan sebanyak 13 kali pertemuan, pada kondisi baseline (A1) peneliti hanya mengamati sebanyak empat kali, kemudian pada kondisi intervensi sebanyak enam kali pengamatan dengan hasil yang meningkat dan pada kondisi baseline (A2) dilakukan sebanyak 3 kali dengan hasil yang sama dari kondisi sebelumnya.

Berdasarkan analisis data hasil perolehan data membuktikkan bahwa keterampilan membedakan toilet pria dan toilet wanita dapat ditingkatkan dengan media kartu gambar.

\section{Daftar Rujukan}

Arief S. Sadiman, R. Rahardjo, Anung Haryono, \& Harjito. (2014). Media Pendidikan

Pengertian, Pengembangan Dan Pemanfaatannta. Jakarta: PT RajaGrafindo Persada.

Dodo Sudrajat, \& Lilis Rosida. (2013). Pendidikan Bina Diri. Bandung: PT. LUMIXA METRO MEDIA.

Ganda Sumekar. (2009). Anak Berkebutuhan Khusus. Padang: Unp Press.

Kasiyati, \& Kusumastuti, G. (2019). Perspektif Pendidikan Anak Tunagrahita. Padang: Sukabina Press.

UU No. 20. (2003). Undang-Undang Republik Indonesia Nomor 20 Tahun 2003 Tentang 
Tarbawi, Volume 5 No. 12020

Gina Hapsari \& Kasiyati, Upaya Meningkatkan Keterampilan

Sistem Pendidikan Nasional. Departemen Pendidikan Nasional, 1-33.

https://doi.org/10.3897/JHR.44.5158 